\title{
EFFECT OF WONDERFUL KOLA SEED MEAL (Buchholzia coriacea) ON GROWTH, MASCULINIZING POTENCY AND GONADAL GROSS MORPHOLOGY OF THE NILE TILAPIA (Oreochromis niloticus, LINNAEUS 1758)
}

\author{
Eze Felix ${ }^{1 *}$ and Eyo Victor Oscar ${ }^{1}$ \\ ${ }^{1}$ Department of Fisheries and Aquaculture, Faculty of Marine Environmental Management, Nigeria Maritime \\ University, Okerenkoko \\ *felixeze8@gmail.com
}

\section{Abstract}

This study was aimed to investigate the effect of Buchholzia coriacea on the masculinization and growth of Oreochromis niloticus. The larva of $O$. niloticus (mean weight $0.2 \mathrm{~g}$, mean length $0.45 \mathrm{~mm}$ ) were subjected to powdered $B$. coriacea seeds meal (BSM) at $0,2,4,6,8,10 \mathrm{~g} / \mathrm{kg}$ twice daily for one month in an indoor experimental plastic basin in duplicates with a total of six treatments. After which they were later fed with a normal diet in an outdoor concrete tank for another one month. The result obtained in this study showed that fish fed with $4 \mathrm{~g} / \mathrm{kg}$ BSM had the highest number $(83.33 \%)$ of males which was significantly higher $(\mathrm{p}<0.05)$ compared to all other treatments categories. The highest survival rate $(100 \%)$ was recorded in fish fed with $6 \mathrm{~g} / \mathrm{kg}$ BSM. The mean weight and weight gain observed are $4.68 \mathrm{~g}$, and $4.65 \mathrm{~g}$ respectively were recorded for fish fed with $4 \mathrm{~g} / \mathrm{kg} \mathrm{BSM}$. The result of the histology showed that $B$. coriacea altered the sex of $O$. niloticus due to the presence of a hormone called dopamine in the kola. Conclusively, B. coriacea showed potential reproduction control in Oreochromis niloticus.

Keywords : Buchholzia coriacea, Growth, Masculinization, Oreochromis niloticus, Traditional herb

\section{INTRODUCTION}

The Nile tilapia (Oreochromis niloticus) belonging to the family Cichlidae, is one of the most popular tilapia species cultured around the world. O. niloticus is very suitable for aquaculture because of its several favorable culturable characteristics such as high fecundity, fast growth, appreciable size, disease resistance, tolerance of harsh environmental conditions, acceptability of formulated feed, high meat quality, high market value, and good taste. Apart from its promising culture characteristics, $O$. niloticus has been used in many areas as biological control of disease vectors of diseases such as bilharzia, malaria, and zika through predation on the hosts of the parasites. On a global scale, $O$. niloticus has rated the $4^{\text {th }}$ most cultured fish species with 2,537 tons in 2010, 3,260 (2012), 3,677 (2014) and 4,200 tons (2016) representing $8 \%$ of the major species produced world aquaculture (FAO, 2018).

In Africa, O. niloticus is responsible for almost half $(43.6 \%)$ of aquaculture production with other freshwater species such as African catfish (Clarias gariepinus) contributing $11.9 \%$ and common carp contributing $10.5 \%$ (FAO, 2018).

Buchholzia coriacea which is commonly also as wonderful kola belongs to the Capparaceae family and it has been used traditionally for medicinal purposes (Mbata et al., 2008). In Nigeria, it is named according to tribes such as Uke (Igbo), Owi (Edo) and Uworo (Yoruba). B. coriacea plant parts including leaves, roots, seeds, and stem are used to increase male sex hormone and their concoctions are useful in treating ailments caused by pathogenic microorganisms including fever, malaria, menstrual and gastrointestinal infections (Amaechi, 2009; Ezeji et al., 2011). In 2016, global fish production peaked around 71 million tonnes, in which aquaculture represented $47 \%$ of the total and $53 \%$ if non-food uses including a reduction to fish oil and fishmeal are excluded (FAO, 2018). With the relative static production in capture fishery since the late $1980 \mathrm{~s}$, sustainable and consistent supply of food fish for human consumption is attributed to aquaculture (FAO, 2018). 
Despite the increase in popularity of tilapia aquaculture, its growth is hindered by their early maturation and proliferated breeding. These problems result in overcrowding of the pond due to an overpopulation of the fish which consequently leads to poor or stunted growth and deterioration of pond water quality (Fashina-Bombata and Busari, 2003). Significant differences in growth of individual attributed to sex have serious consequences for production, including unsalable small fish and variable harvest weight (Lind et al., 2012). Another challenge associated with tilapia culture is sizes of fish at harvest which varies from small to large attributed to fast growth rate and better feed conversion of the male than female. Due to the superior growth rate of males coupled with available sex-reversal techniques, the production of all-male populations is envisaged by a significant proportion of the tilapia aquaculture industry to control the reproduction and improve productivity (Mair et al., 1997).

The magnitude or degree of sexual size dimorphism (SSD) of tilapia now becomes a determinant factor controlling the advantageous growth rate of mono-sex over mixed-sex populations (Lind et al., 2012). One of the most common and frequently used approach to eliminate these problems and control reproduction in tilapia is the monosex male culture strategy. This strategy was first developed in Japan in the 1950s for reversing the sex of aquarium fish and carp species and commercialized in the 1970s (Baroiller and D'Cotta, 2000). In fish, control of reproduction requires gametes manipulation (Mohammadi et al., 2015).

However, basic knowledge on fish reproduction physiology is necessary for developing effective artificial insemination techniques, (Billard and Jensen, 1996). Nowadays, various techniques have been successfully used in controlling reproduction in tilapia such as manual sexing, hybridization, chromosomal manipulation, and hormonal sex reversal
(Bentsen et al., 2012; Megbowon and Mojekwu, 2013).

The use of sex reversal hormonal such as $17 \alpha$-methyltestosterone is seen as the most reliable and simple method of producing all-male tilapia stock, which grows larger at a uniform and faster rate compared to mixed-sex culture (Megbowon and Mojekwu, 2013). However, this technique and other masculinizing technologies are highly expensive, require technical skills, and may not be easily understood and applied by local fish farmers.

Hormonal sex reversal may result in serious environmental issues, fish and public health implications on the treated fish and fish consumers due to the presence of steroids. Also, manual sexing which involves intensive labor may expose fish to handling stress and any sexing error will result in mixed-sex culture. The objective of the present study is to evaluate the effect of wonderful kola seed meal (B. coriacea) on growth, masculinizing potency and gonad gross morphology of the Nile tilapia (Oreochromis niloticus).

\section{METHODOLOGY \\ Place and Time}

The study was carried out in the Fish Hatchery Complex of the Department of Fisheries, University of Maiduguri, Nigeria. Geographically, it is located at Latitude $11.80{ }^{\circ} \mathrm{N}$ and Longitude $13.19^{\circ} \mathrm{E}$ with an elevation 325 meters above sea level.

\section{Research Materials}

The experimental feed was composed of the following ingredients: $B$. coriacea seed, soybeans, wheat bran, trash fish, vitamin C, Vitamin Premix, starch, methionine, and starch. The ingredients were procured from Baga market in Maiduguri. The feedstuffs, including soybeans, wheat bran, and trash fish were separately milled to obtain a fine powder. Soybeans were toasted at $80^{\circ} \mathrm{C}$ for 30 minutes before milling. B. coriacea seeds 
were soaked in water for 24 hours to remove contaminants before air drying. After that, the air-dried grains were milled to fine powder and store in a cold, dry place.

\section{Research Design}

The experiment was set up in a complete randomized design with a total of 6 treatments in duplicate. Sixty (60) 5-day old fry with a total weight range of $0.1-$ $0.3 \mathrm{~g}$ and total length range of $4-5 \mathrm{~mm}$ were stocked in twelve (12) 30 liters capacity trough. The troughs were labeled A1, A2, B1, B2, C1, C2, D1, D2, E1, E2, F1, and F2. Fries stocked in trough A1 and A2 were fed Diet 1 (control) containing $0 \%$ of BSM, B1 and $\mathrm{B} 2$ were fed Diet 2 (2\% BSM), $\mathrm{C} 1$ and C2 were fed Diet 3 (4\% BSM), D1 and D2 were fed Diet 4 (6\% BSM) E1 and E2 were fed Diet 5 (8\% BSM), and F1 and F2 were fed Diet 6 (10\% BSM) respectively.

Feeding was done twice daily adlibitum for 30 days. Uneaten feed was siphoned every morning before feeding the fries to avoid deterioration of the water in the experimental basin. At the end of the 30 days feeding period, the fish were transported into $12\left(1 \mathrm{~m}^{3}\right)$ outdoor concrete pond with the same label given to the trough for another 30 days feeding period before assessing the sexes. During this period, the fish were fed a regular diet of $30 \% \mathrm{CP}$ without B. coriacea Seed Meal (BSM).

\section{Work Procedures \\ Proximate Analysis of the Experimental Diets}

Proximate composition of the six experimental diets was analyzed following standard methods and procedures given by AOAC (2000).

\section{Determination of the Sex of $O$. niloticus Fed Experimental Diets}

At the end of the 30 days feeding period in the outdoor ponds, the sexes of the fish were identified manually with the aid of the gentian violet and cotton. The cotton wool was soaked into gentian violet, and a smear was applied on the genital papilla to see the openings for male or female. The numbers of male and female were recorded.

Table 1. Feed composition of the experimental diets.

\begin{tabular}{lcccccc}
\hline Ingredients (\%) & $\begin{array}{c}\text { Diet A } \\
(0 \%\end{array}$ & $\begin{array}{c}\text { Diet B } \\
(2 \%\end{array}$ & $\begin{array}{c}\text { Diet C } \\
(4 \%\end{array}$ & $\begin{array}{c}\text { Diet D } \\
(6 \%\end{array}$ & $\begin{array}{c}\text { Diet E } \\
(8 \%\end{array}$ & $\begin{array}{c}\text { Diet F } \\
(10 \%\end{array}$ \\
\hline Wheat Bran & 45.36 & 45.36 & 45.36 & 45.36 & 45.36 & 45.36 \\
Fish Meal & 21.67 & 21.67 & 21.67 & 21.67 & 21.67 & 21.67 \\
Soya Bean & 21.67 & 21.67 & 21.67 & 21.67 & 21.67 & 21.67 \\
Premix & 0.3 & 0.3 & 0.3 & 0.3 & 0.3 & 0.3 \\
Vitamin C & 0.05 & 0.05 & 0.05 & 0.05 & 0.05 & 0.05 \\
Salt & 0.3 & 0.3 & 0.3 & 0.3 & 0.3 & 0.3 \\
$\begin{array}{l}\text { Methionine } \\
\text { Lysine }\end{array}$ & 0.35 & 0.35 & 0.35 & 0.35 & 0.35 & 0.35 \\
$\begin{array}{l}\text { Starch } \\
\begin{array}{l}\text { B. coriacea } \\
\text { meal }\end{array}\end{array}$ & 0.3 & 0.3 & 0.3 & 0.3 & 0.3 & 0.3 \\
\hline Total & 10 & 8 & 6 & 4 & 2 & 0 \\
\hline
\end{tabular}


Gonad Gross Morphology of the Experimental Fish

Gonad gross morphology of the experimental fish was evaluated using histological analysis according to Eyo et al. (2014). Gonads of male and female fish (testes and ovaries) fed the six experimental diets were collected processed following the stepwise procedure reported by Brown and Peterson (1911).

The collected gonads were fixed in Bouin's fluid for 4 days before dehydration in alcohol $(30 \%, 50 \%, 70 \%, 90 \%$, and $100 \%$ ). After that, the tissues were cleared in chloroform/xylene solution (50:50) before clearing in pure xylene. The cleared tissues were impregnated in wax before blocking out and sectioning using a rotary microtome at $10 \mu \mathrm{m}$. After sectioning, the tissues were stained using hematoxylin and eosin stain (H\&E) before photomicrograph using Amcap Microscope Camera, Model: DCE - 2 .

\section{Measurement of Water Quality Parameters}

Water quality parameters including $\mathrm{pH}$, dissolved oxygen $(\mathrm{mg} / \mathrm{l})$ and water temperature were measured weekly in each replicate unit of the experiment. $\mathrm{pH}$ was measured using PHEP $\mathrm{pH}$ meter, dissolved oxygen was measured using oxygen meter, and the water temperature was measured using mercury in glass thermometer.

\section{Data Analysis}

Data obtained from the experiment were subjected to one-way analysis of variance (ANOVA) using Predictive Analytical Software (PASW) version 19. Means were separated using the least significance difference (LSD). Effect with a probability of $\mathrm{P}<0.05$ were considered significant.

\section{RESULTS AND DISCUSSION} Sex reversal of $O$. niloticus Fed Diets with Varying Levels of $B$. coriacea seed meal (BSM)

Results obtained for the sex reversal (Table 2) of $O$. niloticus fed diets with varying levels of $B$. coriacea seed meal (BSM) showed that the highest number of males $(83.33 \pm 3.33 \%)$ was recorded in fries fed Diet C (4 g/kg BSM), followed by $74.99 \pm 1.66 \%$ in fries fed Diet E $(8 \mathrm{~g} / \mathrm{kg}$ BSM) and Diet F (10g/kg BSM), followed by $73.33 \pm 3.33 \%$ in fries fed Diet $\mathrm{D}(6 \mathrm{~g} / \mathrm{kg}$ BSM), followed by $54.99 \pm 1.66 \%$ in fries fed Diet B (2 g/kg BSM) and least (51.66 \pm $1.66 \%$ ) in fries fed Diet A (Control).

The least number of females $(16.66 \pm$ $3.33 \%$ ) was recorded in fries fed Diet C (4 $\mathrm{g} / \mathrm{kg} \mathrm{BSM})$, followed by $24.99 \pm 1.66 \%$ in fries fed Diet E (8 g/kg BSM) and Diet F $(10 \mathrm{~g} / \mathrm{kg} \mathrm{BSM})$, followed by $26.66 \pm 3.33 \%$ in fries fed Diet D (6 g/kg BSM), followed by $44.99 \pm 1.66 \%$ in fries fed Diet B ( $2 \mathrm{~g} / \mathrm{kg}$ $\mathrm{BSM})$ and highest $(48.33 \pm 1.66 \%)$ in fries fed Diet A (Control).

Table 2. Sex reversal of $O$. niloticus fed diets with varying levels of $B$. coriacea seed meal (BSM).

\begin{tabular}{ccccccc}
\hline Sex & $\begin{array}{c}\text { Diet A } \\
(0 \% \text { BSM })\end{array}$ & $\begin{array}{c}\text { Diet B } \\
(2 \% \text { BSM })\end{array}$ & $\begin{array}{c}\text { Diet C } \\
(4 \% \text { BSM })\end{array}$ & $\begin{array}{c}\text { Diet D } \\
(6 \% \text { BSM })\end{array}$ & $\begin{array}{c}\text { Diet E } \\
(8 \% \text { BSM })\end{array}$ & $\begin{array}{c}\text { Diet F } \\
(10 \% \text { BSM })\end{array}$ \\
\hline $\begin{array}{c}\text { No. of } \\
\text { Males } \\
(\%)\end{array}$ & $51.66 \pm 1.66^{\mathrm{a}}$ & $54.99 \pm 21.66^{\mathrm{a}}$ & $83.33 \pm 3.33^{\mathrm{a}}$ & $73.33 \pm 3.33^{\mathrm{a}}$ & $74.99 \pm 1.66^{\mathrm{a}}$ & $74.99 \pm 1.66^{\mathrm{a}}$ \\
$\begin{array}{c}\text { No. of } \\
\text { Females } \\
(\%)\end{array}$ & $48.33 \pm 1.66^{\mathrm{a}}$ & $44.99 \pm 21.66^{\mathrm{a}}$ & $16.66 \pm 3.33^{\mathrm{a}}$ & $26.66 \pm 3.33 \mathrm{a}$ & $24.99 \pm 1.66 \mathrm{a}$ & $24.99 \pm 1.66 \mathrm{a}$ \\
\hline
\end{tabular}




\section{Water Quality Parameters of the Experimental Units}

Results of water quality parameters (Table 3) showed that the highest temperature $\left(28.25 \pm 0.05^{\circ} \mathrm{C}\right)$ for the indoor tank was recorded in experimental plastic tank one and the highest temperature for the outdoor tank $\left(28.25 \pm 0.15^{\circ} \mathrm{C}\right)$ was recorded in concrete tank 2 . The lowest temperature $\left(26.65 \pm 0.25{ }^{\circ} \mathrm{C}\right.$ and $\left.27.65 \pm 0.65{ }^{\circ} \mathrm{C}\right)$ was recorded in experimental plastic tank 3 and concrete tank 4 (outdoor) respectively. For $\mathrm{pH}$, the highest value for indoor and outdoor tanks $(8.47 \pm 0.03)$ was recorded in plastic tank 4 and concrete tank 4 respectively. The lowest $\mathrm{pH}$ value of for indoor and outdoor tanks $(8.33 \pm 0.07)$ was recorded in plastic tank 6 and concrete tanks 1, 2, and 3 .

The highest value of dissolved oxygen for indoor and outdoor tanks (5.57 $\pm 0.07 \mathrm{mg} / \mathrm{l}$ and $5.75 \pm 0.05 \mathrm{mg} / \mathrm{l}$ ) was recorded in plastic tank 2 and concrete tank 1 and 4 respectively. The lowest value of dissolved oxygen for indoor and outdoor tanks $(5.44 \pm 0.03 \mathrm{mg} / \mathrm{l}$ and $5.55 \pm 0.05$ $\mathrm{mg} / \mathrm{l})$ was recorded in plastic tank 1 and concrete tank 2.

Table 3. Mean water quality parameter for both indoor and outdoor experimental tanks.

\begin{tabular}{ccccccc}
\hline $\begin{array}{c}\text { Experimental } \\
\text { Tank }\end{array}$ & $\begin{array}{c}\text { Temperature } \\
\left({ }^{\circ} C\right)\end{array}$ & $\begin{array}{c}\text { Indoor } \\
\mathrm{pH}\end{array}$ & DO $(\mathrm{mg} / \mathrm{l})$ & $\begin{array}{c}\text { Temperature } \\
\left({ }^{\circ} \mathrm{C}\right)\end{array}$ & $\begin{array}{c}\text { Outdoor } \\
\mathrm{pH}\end{array}$ & DO $(\mathrm{mg} / \mathrm{l})$ \\
\hline 0 & $26.75 \pm 0.25^{\mathrm{a}}$ & $8.45 \pm 0.01^{\mathrm{a}}$ & $5.63 \pm 0.65^{\mathrm{a}}$ & $28.50 \pm 0.5^{\mathrm{a}}$ & $8.33 \pm 0.01^{\mathrm{c}}$ & $5.75 \pm 0.05^{\mathrm{a}}$ \\
2 & $28.25 \pm 0.05^{\mathrm{a}}$ & $8.40 \pm 0.25^{\mathrm{b}}$ & $5.57 \pm 0.07^{\mathrm{ab}}$ & $28.65 \pm 0.15^{\mathrm{a}}$ & $8.33 \pm 0.03^{\mathrm{c}}$ & $5.55 \pm 0.05^{\mathrm{c}}$ \\
4 & $27.85 \pm 0.05^{\mathrm{a}}$ & $8.37 \pm 0.08^{\mathrm{c}}$ & $5.56 \pm 0.01^{\mathrm{ab}}$ & $27.65 \pm 0.65^{\mathrm{a}}$ & $8.33 \pm 0.03^{\mathrm{b}}$ & $5.56 \pm 0.01^{\mathrm{abc}}$ \\
6 & $27.00 \pm 1.00^{\mathrm{a}}$ & $8.45 \pm 0.01^{\mathrm{a}}$ & $5.44 \pm 0.03^{\mathrm{b}}$ & $28.50 \pm 0.80^{\mathrm{a}}$ & $8.47 \pm 0.03^{\mathrm{b}}$ & $5.75 \pm 0.05^{\mathrm{a}}$ \\
8 & $27.75 \pm 0.75^{\mathrm{a}}$ & $8.47 \pm 0.03^{\mathrm{ab}}$ & $5.61 \pm 0.05^{\mathrm{ab}}$ & $28.15 \pm 0.35^{\mathrm{a}}$ & $8.45 \pm 0.00^{\mathrm{b}}$ & $5.60 \pm 0.00^{\mathrm{bc}}$ \\
10 & $27.55 \pm 0.75^{\mathrm{a}}$ & $8.33 \pm 0.03^{\mathrm{c}}$ & $5.61 \pm 0.05^{\mathrm{a}}$ & $28.15 \pm 0.35^{\mathrm{a}}$ & $8.45 \pm 0.01^{\mathrm{a}}$ & $5.60 \pm 0.00^{\mathrm{ab}}$
\end{tabular}

Note : means with the same superscript are not significantly different $(\mathrm{P}>0.05)$

\section{Sex Reversal}

B. coriacea seed meal (BSM) has been reported to significantly increase Luteinizing Hormone (LH), testosterone, Follicle Stimulating Hormone (FSH), elevator anti muscle weight, prolactin hormone levels, motility and sperm count in infertile obese mutant rat models (Kumar, 2002). Additionally, B. coriacea seed meal (BSM) has been used to increase libido in men due to its dopamine inducing properties (Shukla et al., 2010; Giuliano and Allard, 2001). The results of this study showed that each treated group gave a mean male/female ratio that deviate significantly from the normal $1: 1$ ratio, with a significantly higher $(\mathrm{P}<0.05)$ male ratio compared to than females.

The success of sex-reversal experiments is usually evaluated using a percentage of males which is to a large extent dependent on the intake feed treated with the hormone (Baroiller et al., 1995). According to Mair and Little (1991) and ElSayed (2006), hormone administration through feed intake is influenced by several factors including treated feed quality, feed ingredients composition and processing methods, feed storage, ingredients particle size, and feed palatability. The control group was very close to the normal 1:1 ratio. This indicates that the variation in male to female ratio in fish fed $B$. coriacea supplemented diets compared to the control fish observed in this study could be due to the effect of B. coriacea seed meal (BSM) present in the diets.

Adhikari (2019) reported the efficacy of $B$. coriacea seeds in the treatment of 
several sexual asthenia and infertility in human implying that it contains androgens.

Also, the methanol extract of its leaves stimulated testosterone production in testicular fractions and Leydig cell cultures in the average adult albino male rat. In this study, none of the feed containing varying levels of B. coriacea seed meal (BSM) gave $100 \%$ male population of $O$. niloticus implying that $B$. coriacea seed is not efficient in tilapia sex reversal. The use of steroids as masculinizing agents in tilapia culture has been reported to be $90-100 \%$ efficient in Sarotherodon niloticus, $O$. mossambicus and O. niloticus (Tayamen and Shelton 1978; Pandian and Koteeswaran, 1998).

These results are higher than $83.33 \%$ males recorded in this study for $O$. niloticus fed Diet C (4 \% BSM). The highest number of males $83.33 \%$ recorded in this study for O. niloticus fed Diet C (4\% BSM) is lower than $92 \%$ of males reported by Chukwu and Shaba (2009) after treating O. niloticus with $8 \mathrm{~g} / \mathrm{kg}$ of pawpaw seed for 60 days. The $83.33 \%$ males $O$. niloticus obtained in this study could be attributed to the time of commencement of experimental diet administration which was from one-weekold fry weighing $0.2 \mathrm{~g}$.

However, these findings are better than $73.33 \%$ obtained by Mukerjee et al. (2015) after feeding O. niloticus with diets formulated with Mucuna puriens seed meal at $5.0 \mathrm{~g} / \mathrm{kg}$ for 40 days. Interestingly, fish fed diet $\mathrm{D}(6 \mathrm{~g} / \mathrm{kg} \mathrm{BSM})$ recorded the same percentage $(73.33 \%)$ for males obtained by Mukherjee et al., (2015) after feeding $O$. niloticus with a diet containing at $5.0 \mathrm{~g} / \mathrm{kg}$ of M. puriens seed meal.

Findings of this study are however, higher than the findings of Okoko (1996), who obtained $71.9 \%$ males at the dose rate of $120 \mathrm{mg} \mathrm{kg}-1 \mathrm{MT}$ of feed. The results of this study showed a significantly lower $(\mathrm{P}<0.05)$ male proportion of $74.99 \%$ for the highest dose rate of $B$. coriacea seed meal of $10 \mathrm{~g} / \mathrm{kg}$. These results are in line with the findings of Okoko (1996), who obtained $99.3 \%$ males at $30 \mathrm{mg} \mathrm{MT}$, while 97 and
$71.9 \%$ males at the dose rates of 60 and 120 mg MT, respectively. These findings imply that a higher dose rate of $B$. coriacea seed in O. niloticus diets did not yield to a higher percentage of male. $4 \mathrm{~g} / \mathrm{kg}$ BSM recorded the highest male production because it was included in the optimum quantity.

\section{Gonad morphology}

In this study, the histology of female gonads of $O$. niloticus treated with $B$. coriacea seed showed no sign of gonads development. This is because the number of days $O$. niloticus fry was fed with $B$. coriacea seed meal was relatively low (30 days) compared to Jegede and Fagbenro (2008) in a related study of $O$. niloticus fed with varying levels of $C$. papaya which lasted for 60 days. The features of the male testis are still developing; hence, no effect was observed. Thus, if the period for 30 days of feeding $O$. niloticus with $B$. coriacea based feed is prolonged, there is a tendency that the ovaries and the testis may disintegrate.

\section{CONCLUSION}

The result emanating from this study can be used as an alternative method to produce all-male tilapia population in an environmentally friendly manner using a natural product. However, the inclusion of $\mathrm{BSM}$ at the recommended quantity has no adverse effect on the gonad morphology of fish.

\section{REFERENCES}

Adesule, E.A., 1997. Current status of tilapia in Nigerian Aquaculture. Proceedings of the 4th International Symposium on Tilapia in Aquaculture. 2, pp.577-583.

Adhikari, A., 2019. Bioprospecting Studies on Sarcococca Coriacea (Hook. F.) of Nepalese Origin (Doctoral dissertation).

Amaechi, N.C., 2009. Nutritive and AntiNutritive evaluation of Wonderful kola (Buchholzia coricea) seeds. 
Pakistan Journal of Nutrition, 8(8), pp.1120-1122.

Association of Official Analytical Chemists, A.O.A.C., 2006. Official Methods of Analysis of A. O. A. C. International. (17th Ed.). Washington, US.

Baroiller, J.F., Chourrout, D., Fostier, A., and Jalabert, B., 1995. Temperature and sex chromosomes govern sex ratios of the mouthbrooding cichlid fish Oreochromis niloticus (L.). Journal of experimental zoology, 273(3), pp.216-223.

Baroiller, J.F. and D'Cotta, H., 2000. Involvement of steroids in the natural and temperature-induced sex differentiation in the tilapia, $O$. niloticus. In: Proceedings of the Internation-al Symposium on the Molecular Mechanisms of Morphogenesis in the Early Development of Fish, National Re-search Institute of Aquaculture, Mie, Japan (Vol. 72).

Belal, I.E. and Al-Jasser, M.S., 2000. Replacing dietary starch with pitted date fruit in Nile tilapia Oreochromis niloticus (L.) feed. Aquaculture Research, 28(6), pp.385-389.

Bentsen, H.B., Gjerde, B., Nguyen, N.H., Rye, M., Ponzoni, R.W., de Vera, M.S.P., Bolivar, H.L., Velasco,R.R., Danting, J.C., Dionisio, E.E., Longalong, F.M., Reyes, R.A., Abella, T.A., Tayamen, M.M. and Eknath, A.E., 2012. Genetic improvement of farmed tilapias: genetic parameters for body weight at harvest in Nile tilapia (Oreochromis niloticus) during five generations of testing in multiple environments. Aquaculture, 338, pp.56-65.

Billard, R. and Jensen, J.J.O., 1996. Gamete removal, fertilization and incubation. In Developments in aquaculture and fisheries science (Vol. 29, pp. 291364). Elsevier.

Brown Jr, H.P. and Peterson Jr, J.H., 1991. Assessing spirituality in addiction treatment and follow-up:
Development of the Brown-Peterson Recovery Progress Inventory (BPRPI). Alcoholism Treatment Quarterly, 8(2), pp.21-50.

Chukwu, O. and Shaba, I.M., 2009. Effects of drying methods on proximate compositions of catfish (Clarias gariepinus). World journal of agricultural sciences, 5(1), pp.114116.

El-Sayed, A-F.M., 2006. Tilapia Culture. CABI, Wallingford, Oxfordshire, United Kingdom. 111, p1901.

Eyo, V.O., Ekanem, A.P. and Jimmy, U.I.U., 2014. A comparative study of the gonado-somatic index (gsi) and gonad gross morphology of African catfish (Clarias gariepinus) fed unical aqua feed and coppens commercial feed. Croatian Journal of Fisheries: Ribarstvo, 72(2), pp.63-69.

Ezeji, M.I., Ezeigbo, I.I., and Madubuike, K.G., 2011. Analgesic activity of the methanolic seed of Buchholzia coriacea. Research Journal of Pharmaceutical, Biological and chemical Science., 2(1): pp.187-193.

FAO, 2018. Fisheries Department, Fishery Information, Data and Statistics Unit. Fishstat Plus: Vers. 2. fingerlings in Philippines. pp.183-186.

Fashina-Bombata, H.A. and Busari, A.N., 2003. Influence of salinity on the developmental stages of African catfish Heterobranchus longifilis (Valenciennes, 1840). Aquaculture, 224(1-4), pp.213-222.

Giuliano, F. and Allard, J., 2001. Dopamine and sexual function. International journal of impotence research, 13(S3), pp.S18-S28.

Jegede, T. and Fagbenro, O., 2008. Histology of gonads in Tilapia zillii (Gervais) fed Neem (Azadirachta indica) leaf meal diets. In $8 t h$ International symposium on tilapia aquaculture. Cairo, Egypt. pp.11291134.

Kumar, A., 2002. Cytological investigations in some important tree 
species of Rajasthan III Karyomorphological investigations in the genus Salvadora (L). Ind. J. Forestry, 25, pp.326-330.

Lind, C.E., Ponzoni, R.W., Nguyen, N.H. and Khaw, H.L., 2012. Selective breeding in fish and conservation of genetic resources for aquaculture. Reproduction in domestic animals, 47, pp.255-263.

Mair, G.C. and Little, D.C., 1991. Population control in farmed tilapias. Naga, the ICLARM Quarterly, 14(3), pp.8-13.

Mair, G.C., Abucay, J.S., Abella, T.A., Beardmore, J.A. and Skibinski, D.O.F., 1997. Genetic manipulation of sex ratio for the large-scale production of all-male tilapia Oreochromis niloticus. Canadian Journal of Fisheries and Aquatic Sciences, 54(2), pp.396-404.

Mbata, T.I., Debiao, L.U. and Saikia, A., 2008. Antibacterial activity of the crude extract of Chinese green tea (Camellia sinensis) on Listeria monocytogenes. African journal of Biotechnology, 7(10). pp.1571-1573.

Megbowon, I. and Mojekwu, T.O., 2013. Tilapia sex reversal using methyl testosterone (MT) and its effect on fish, man and environment.

Mohammadi, H., Khara, H. and Kazemi, R., 2015. Effect of different doses of synthetic hormone LHRH-A2 on serum sex hormones, ovulation percent and egg hatching rates of Persian sturgeon Acipenser persicus. Croatian Journal of Fisheries, 73(2), pp.58-62.

Mukherjee, D., Ghosal, I. and Chakraborty, S.B., 2015. Production of monosex Nile Tilapia, Oreochromis niloticus using seed of Mucuna pruriens. IOSR (International Organization of Scientific Research) Journal of Pharmacy and Biological Sciences, 10, pp.55-59.

Okoko, M., 1996. Effect of 17-alphamethyl testosterone concentrations on the sex ratio and gonadal development of Nile tilapia Oreochromis niloticus. Masters Thesis, Auburn University, Alabama, US. pp.203-207.

Pandian, T.A. and Koteeswaran, R., 1998. Ploidy induction and sex control in fish. Hydrobiologia, 384(1-3), pp.167-243.

Shukla, K.K., Mahdi, A.A., Ahmad, M.K., Jaiswar, S.P., Shankwar, S.N. and Tiwari, S.C., 2010. Mucuna pruriens reduces stress and improves the quality of semen in infertile men. Evidence-Based Complementary and Alternative Medicine, 7(1), pp.137144.

Tayamen, M.M., and Shelton, W.L., 1978. Inducement of sex reversal in Sarotherodon niloticus (Linnaeus). Aquaculture, 14(4), pp.349-354. 